\title{
Effect of nitric oxide inhibitor and donor substances on the inflammatory process caused by endodontic irrigants
}

Luciana Malheiro de BRITO1, Cláudia de Moura CARREIRA², Denise Pontes RALDI ${ }^{3}$ José Luiz LAGE-MARQUES ${ }^{4}$, Sandra Márcia HABITANTE ${ }^{3}$, Wilson Abraão SAAD ${ }^{3}$

1- DDS, MSc of Endodontics, Postgraduate Program in Dentistry, Department of Dentistry, University of Taubaté, Taubaté, $\mathrm{SP}$, Brazil.

2- DDS, MSc, PhD of Endodontics, Postgraduate Program in Dentistry, University of São Paulo, São Paulo, SP, Brazil.

3- DDS, MSc, PhD, Professor of Postgraduate Program in Dentistry, Department of Dentistry, University of Taubaté, Taubaté, $\mathrm{SP}$, Brazil.

4- DDS, MSc, PhD, Associated Professor of Endodontics, Department of Dentistry, University of São Paulo, São Paulo, SP, Brazil; Endodontics Coordinator of the Postgraduate Program in Dentistry, Department of Dentistry, University of Taubaté, Taubaté, SP, Brazil.

Corresponding address: Profa Dra Denise Pontes Raldi - Rua Expedicionário Ernesto Pereira, 110 - 12020 -330 - Taubaté - SP - Brasil - Phone/Fax: +55-12-3625-4149 - e-mail: pontesdenise@uol.com.br

Received: June 1, 2009 - Modification: April 30, 2010 - Accepted: May 21, 2010

\section{ABSTRACT}

$\mathrm{N}$ itric oxide (NO) has been considered a key molecule in inflammation. Objective: The aim of this study was to evaluate the effect of treatment with L-NAME and sodium nitroprussiate, substances that inhibit and release NO, respectively, on tissue tolerance to endodontic irrigants. Material and Methods: The vital dye exudation method was used in a rat subcutaneous tissue model. Injections of $2 \%$ Evans blue were administered intravenously into the dorsal penial vein of 14 male rats (200-300 g). The NO inhibitor and donor substances were injected into the subcutaneous tissue in the dorsal region, forming two groups of animals: G1 was inoculated with L-NAME and G2 with sodium nitroprussiate. Both groups received injections of the test endodontic irrigants: acetic acid, $15 \%$ citric acid, 17\% EDTA-T and saline (control). After $30 \mathrm{~min}$, analysis of the extravasated dye was performed by light absorption spectrophotometry $(620 \mathrm{~nm})$. Results: There was statistically significant difference $(p<0.05)$ between groups 1 and 2 for all irrigants. L-NAME produced a less intense inflammatory reaction and nitroprussiate intensified this process. Conclusions: Independently of the administration of NO inhibitors and donors, EDTA-T produced the highest irritating potential in vital tissue among the tested irrigating solutions.

Key words: Nitric oxide. Inflammation. Root canal irrigants.

\section{INTRODUCTION}

Chemical substances should act without being aggressive to the pulp and periapical tissues. Considering that the chemical substances used during chemomechanical preparation of root canals can extrude to the periapical region, and that the chemical agents used are tissue irritatings, it is important to know the consequences of their contact with vital tissues, in order to minimize postoperative complications. All substances that come into contact with vital tissues require previous biocompatibility tests.

When a tissue is damaged, a normal protective response is set off: inflammation. The inflammatory response starts by the release of chemical mediators, produced by the cells of the affected tissue, which promote vasodilation and increase the 
blood flow, resulting in an accumulation of liquid and blood cells. The vasodilation phenomenon occurs as a result of the action of a substance produced in the endothelium, denominated endothelium derived relaxation factor (EDRF) ${ }^{4}$. Palmer, Ferrige and Moncada $^{15}$ (1987) and Ignarro, et al. ${ }^{8}(1987)$ suggested that this factor was nitric oxide (NO) because of the similarities in their physicochemical characteristics.

In 1992, the scientific journal Science ${ }^{11}$ recognized the importance of this substance in various areas of Medicine, and named it the "Molecule of the Year". Since then, a increased number of studies on NO and its metabolites have progressively allowed an understanding of some of its main biological functions: participation in the immunological system, neurotransmission and vasodilation ${ }^{5,13}$. Furthermore, a variety of cardiovascular and cerebral problems and inflammatory and infectious diseases may be related to a high or low NO level in the organism ${ }^{6}$.

NO is synthesized by the enzyme nitric oxide synthase (NOS), which is present in a variety of different cell types, or is induced by an external mechanism, such as immunological and inflammatory stimuli ${ }^{5}$. Dental pulp presents the potential to produce NO, since NOS is present in endothelial cells, odontoblasts, nerve tissues, white blood cells and vascular smooth muscles ${ }^{10}$. Analyzing NOS production, NO has been found to be synthesized in root cysts ${ }^{26}$ and inflamed periapical tissues $^{3,18}$, playing a decisive role in the regulation of chronic, periapical infection ${ }^{25}$.

After obtaining good results with inhibitory substances on cells removed from periapical cysts, Takeichi, et al. ${ }^{24}$ (1999) suggested the use of NO inhibitors in the root canal as a pharmacological treatment for periapical lesions.

There are several studies correlating NO with endodontic sealers or periapical lesions ${ }^{3,18,20,24}$, but only one relating it to chemical irrigant substances ${ }^{16}$. Laboratory determination of NO is complex, and characterization of its specific activators and inhibitors constitutes a new challenge to the understanding and treatment of various diseases.

The solutions commonly used in the final irrigation of endodontic therapy are citric acid and EDTA $^{12,21}$, and more recent research has also suggested acetic acid ${ }^{22}$. The use of these irrigants has been extensively studied ${ }^{12,21,23}$. It would be interesting to accelerate the healing process, in order to obtain a better control of the inflammatory process, and to provide more comfort to the patient. Thus, the aim of this study was to evaluate the effects of the treatment with L-NAME and sodium nitroprussiate, substances that block and release NO, respectively, in connective tissue inflammation caused by acetic acid, citric acid, EDTA-T irrigants.

\section{MATERIAL AND METHODS}

This study was approved by the Ethics Committee of the Dental School of the University of Taubaté, Brazil (protocol 07/2005).

The following endodontic irrigants, prepared at Fórmula \& Ação pharmacy (São Paulo, SP, Brazil), were evaluated:

- 17\% EDTA-T (ethylenediaminetetraacetic acid disodium - tergentol) - The salt EDTA was weighed $(17 \mathrm{~g})$, diluted in $100 \mathrm{~mL}$ of tergentol and the $\mathrm{pH}$ was adjusted to 7.3 with sodium hydroxide solution.

- 15\% citric acid - The salt (Merck S.A., São Paulo, SP, Brazil) was weighed, diluted in deionized, and the $\mathrm{pH}$ was adjusted to 1.0 using $\mathrm{pH}$ meter (B371; Micronal, São Paulo, SP, Brazil).

- $10 \%$ acetic acid - $10 \mathrm{~g}$ of 2-hydroxypropane tricarboxylic acid was diluted in (qsp) $100 \mathrm{~mL}$ of bidistilled water.

- Saline solution (used as control).

L-NAME ( $\mathrm{N}^{\mathrm{G}}$-nitro-L-arginine methyl ester) and sodium nitroprussiate were purchased from Tocris Cookson Inc.(St. Louis, MO, USA).

\section{Vital dye exudation technique}

The experiment was performed according to the technique proposed by Udaka, et al. ${ }^{27}$ (1970). Fourteen male Wistar rats (Rattus novergicus, albinus), weighing between 200-300 g, were obtained from the Animal Care Facility of the Araraquara Dental School, São Paulo State University, Brazil. They were kept in cages, in a suitable environment, at the Pharmacological Laboratory of the Medical School of the University of Taubaté, Brazil.

The animals were anesthetized with intraperitoneal administration of Thiopentax ${ }^{\circledR}(0.3$ $\mathrm{mL}$ for every $100 \mathrm{~g} / \mathrm{rat}$ ) in the lateral caudal region. After, 2\% Evans vital blue dye (Sigma Chemical Co., St. Louis, MO, USA) was injected intravenously in the dorsal penial vein, at the dose of $20 \mathrm{mg} / \mathrm{kg}$ of body weight. A sufficient period was waited to ensure that the dye injection had been successfully administered (around $3 \mathrm{~h}$ ) observing the blue stain in the irises of the rats. After that, the dorsal region was shaved and the animals were randomly divided into 2 groups $(n=7)$ :

Group 1: at four predetermined sites in the dorsal region of the rats, $0.1 \mathrm{~mL}$ of L-NAME, a NO inhibitor ( $30 \mathrm{mg} / \mathrm{kg}$ dissolved in $5 \mathrm{~mL}$ of saline solution), was injected into the subcutaneous tissue. Afterwards, $0.1 \mathrm{~mL}$ of each tested solution (EDTA, citric acid, acetic acid and saline) was injected in each point.

Group 2: at four predetermined sites in the subcutaneous tissue, $0.1 \mathrm{~mL}$ of sodium nitroprussiate, a NO donor $(4 \mathrm{mg} / \mathrm{kg}$ dissolved in 40 $\mathrm{mL}$ of saline), was injected into the subcutaneous tissue. Afterwards, $0.1 \mathrm{~mL}$ of each tested solution 
(EDTA, citric acid, acetic acid and saline) was injected in each point.

The substances were used in a system of rounds, in such a way that the same animal would receive the three irrigants, in addition to the control solution. Concomitantly with NO inhibitor or donor substances, the irrigants were applied, according to their respective groups.

After 30 min the animals were sacrificed by anesthetic overdose (Thiopentax ${ }^{\circledR}-0.6 \mathrm{~mL}$ for every $100 \mathrm{~g}$ body weight) and their dorsal skins were excised using an iron ring with an active tip ( $3 \mathrm{~cm}$ in diameter), with a safety margin of $20 \mathrm{~mm}$ beyond the bluish colored edema haloes formed by the medication.

The tissue obtained was fragmented, immersed in $10 \%$ formalin and kept in water at $37^{\circ} \mathrm{C}$ for $72 \mathrm{~h}$ for complete extraction of the dye. After $72 \mathrm{~h}$, the resulting solutions were subjected to spectrophotometric analysis (Cary 50 Bio UV Visible Spectrophotomer; Varian Inc., San Francisco, CA, USA) at $620 \mathrm{~nm}$ wavelength (maximum absorbance capacity of the Evans blue dye), and calibrated for optical density reading, according to the evaluation criteria of the irritating potential of substances proposed by Nagem-Filho and Pereira ${ }^{14}$ (1976) (Figure 1).

\section{Statistical Analysis}

The obtained data were examined for the adherence to the normality curve and submitted to statistical analysis by the Kruskal-Wallis test for individual comparison at a level of significance of $5 \%(p<0.05)$.

\begin{tabular}{|c|c|}
\hline Absorbance values & Degree of irritation potencial \\
\hline $0.0000-0.1249$ & Not significant \\
\hline $0.1249-0.3010$ & Discrete \\
\hline $0.3010-0.6201$ & Moderate \\
\hline $0.6201-2.0000$ & Severe \\
\hline
\end{tabular}

Figura 1- Criteria for evaluating the irritating potential of substances according to the absorbance values (A620) Nagem-Filho and Pereira ${ }^{14}$ (1976)

\section{RESULTS}

The data presented in the Table 1 define the irritating potential of the irrigants (acetic acid, citric acid, EDTA-T and saline) correlating them with the treatment with sodium nitroprussiate and L-NAME, substances that release and inhibit NO, respectively.

Table 1 shows the dye absorbance means and their correlation with the irritating potential of the irrigants used and the standard deviations. Analysis of the solutions by spectrophotometry showed lower light absorbance by the irrigants in the group in which NO inhibitor (L-NAME) was used. There were statistically significant differences $(p<0.05)$ among the irrigants in each group when the NO inhibitor and donor substances were compared.

\section{DISCUSSION}

Endodontic intervention produces an inflammatory reaction which, depending on the intensity, can interfere in the repair and healing process, and consequently in the control of the inflammation ${ }^{21}$. Over the last few years, a large number of studies have considered NO as a key molecule in inflammatory processes. The action of NO can vary, depending on the source and quantity of produced ${ }^{5,13}$.

In this study, it can be observed that the administration of a NO releasing agent (sodium nitroprussiate) produced an intensification of the inflammatory process. On the other hand, the application of NO blocking substance (L-NAME), was able to reduce significantly the inflammatory reaction.

When chemical substances are used during endodontic treatment, it may inadvertently extrude to the periapical region and promote an acute initial inflammation. For this reason, it was opted to evaluate the irrigants in vital tissues. Another decisive factor on this regard was the results of Takeichi, et al. ${ }^{24}$ (1999), who suggested the use of NO inhibitors in the root canal as a pharmacological treatment for periapical lesions. It motivates the evaluation of chemical substances and their

Table 1- Mean and standard deviation of optic density reading obtained by the spectrophotometer, corresponding to the degree of irritation - Nagem-Filho and Pereira ${ }^{14}$ (1976).

\begin{tabular}{ccccc}
\hline $\begin{array}{c}\text { Tested } \\
\text { substances }\end{array}$ & $\begin{array}{c}\text { Sodium Nitroprussiate } \\
\text { (Means } \pm \text { Standard deviation) }\end{array}$ & $\begin{array}{c}\text { Degree of } \\
\text { irritation }\end{array}$ & $\begin{array}{c}\text { L-NAME } \\
\text { (Means } \pm \text { Standard deviation) }\end{array}$ & $\begin{array}{c}\text { Degree } \\
\text { of irritation }\end{array}$ \\
\hline Acetic acid & $0.279 \pm 0.344^{\mathrm{b}}$ & discrete & $0.021 \pm 0.011^{\mathrm{a}}$ & not significant \\
Citric acid & $0.072 \pm 0.045^{\mathrm{b}}$ & not significant & $0.008 \pm 0.008^{\mathrm{a}}$ & not significant \\
EDTA-T & $1.300 \pm 0.418^{\mathrm{b}}$ & severe & $0.155 \pm 0.111^{\mathrm{a}}$ & discrete \\
Saline solution & $0.077 \pm 0.057^{\mathrm{b}}$ & not significant & $0.011 \pm 0.006^{\mathrm{a}}$ & not significant \\
\hline
\end{tabular}

Statistical differences are indicated by different lletters in rows (Kruskal Wallis test, $\mathrm{P}<0.05$ ). 
correlation with $\mathrm{NO}$, a fact that had not been studied previously.

In order to quantify the irritating potential of a substance inoculated in vivo, the method proposed by Udaka, et al. ${ }^{27}$ (1970), has frequently been used. This was based on the evaluation of the exudate produced due to the increase in vascular permeability, as a result of the irritating potential of the tested substances, and which were inferred by the spectrophotometric measurements of the extravasated vital dye. Thus, the method is useful not only to quantify the inflammatory exudates elicited by phlogistic agents ${ }^{2,19,21}$, but also to evaluated the efficacy of antiinflammatory drugs ${ }^{7,9}$. The vital dye exudation technique was conducted as previously described $14,21,27$.

Nagem-Filho and Pereira ${ }^{14}$ (1976) established complementary evaluation criteria for the vital dye exudation technique. The absorbance values $\left(A^{620}\right)$, which translate the amount of dye exudate proportionally, relative to the irritating potential of the tested substances, were divided into 4 degrees: not significant, discrete, moderate and severe. Comparing the table of absorbance values $\left(A^{620}\right)$ proposed by Nagem-Filho and Pereira ${ }^{14}(1976)$ to the values obtained in this study (Table 1 ), it can be observed that, for both NO inhibitor and donor substances, EDTA-T presented a higher irritating potential in vital tissues than the other irrigants. However, it is important to emphasize that this analysis was performed in the initial stage of inflammation.

Some studies ${ }^{1,17,28}$ have described that the ideal concentration of EDTA ranging from $10 \%$ and $17 \%$. Citric acid concentration at $15 \%$ was chosen based on a previous study ${ }^{12}$ that evaluated the demineralizing effect of this solution at $5 \%, 10 \%$, $15 \%$ and $25 \%$.

Although all endodontic irrigants in the sodium nitroprussiate group (G2) presented a higher irritating potential than in the L-NAME group (G1), the acetic acid solution and particularly EDTA-T presented a greater irritating potential. Citric acid and saline showed similar results and were less aggressive than the other two solutions in contact with vital tissues.

EDTA and citric acid have been used in Dentistry for years and have wide clinical applicability. The considerations in the literature about their irritating potential suggest that independently of the solution used, it should be applied in a safe manner, with caution, due to its action on periapical tissues ${ }^{12,21}$. However, studies related to acetic acid are new, and further studies should be conducted as regards its biocompatibility.

It is well known that the action of NO in immunoregulation is present in inflammation and in the autoimmunity mechanisms ${ }^{3,5,13,18}$. Therefore, further investigations regarding the determination of specific activators and inhibitors of NO synthesis constitutes a new challenge to the understanding and treatment of various diseases. As there are not so many studies in dentistry showing the role of NO in the inflammatory process, further investigations are needed to produce relevant knowledge in this area that can be clinically applicable in Endodontics.

\section{CONCLUSION}

Based on the conditions established by the experiment, it can be concluded that:

1. Sodium nitroprussiate and L-NAME changed the inflammatory reaction produced by tested irrigants.

2. The inflammatory reaction was more intense in the group submitted to treatment with sodium nitroprussiate.

3. In the group in which the NO inhibitor (L-NAME) was administered, there was a reduction in the inflammatory process.

4. Independently of the administration of NO inhibitor or donor substances, EDTA-T had the highest irritating potential in vital tissue among the tested irrigating solutions.

\section{REFERENCES}

1- Berutti E, Marini R, Angeretti A. Penetration ability of different irrigants into dentinal tubules. J Endod. 1997;23(12):725-7.

2- Busch L, Tessler J, Bazerque PM. Effects of calcium and EDTA on rat skin capillary permeability and its response to histamine, serotonin and bradykinin. Acta Physiol Pharmacol Latinoamer. 1989;39(3):227-34.

3- Fukada SY, Silva TA, Saconato IF, Garlet GP, Avila-Campos MJ, Silva JS, et al. iNOS-derived nitric oxide modulates infectionstimulated bone loss. J Dent Res. 2008;87(12):1155-9.

4- Furchgott RF, Zawadazki JV. The obligatory role of endothelial cells in the relaxation of arterial smooth muscle by acethylcholine. Nature. 1980;288(5789):373-6.

5- Gaston B, Drazen JM, Loscalzo J, Stamler JS. The biology of nitrogen oxides in the airways. Am J Respir Crit Care Med. 1994;149(2 pt 1):538-51.

6- Granik VG, Ryabova SY, Grigoriev NB. Exogenous nitric oxide donors and inhibitors of its formation (the chemical aspects). Russ Chem Rev. 1997;66:717-31.

7- Guimarães SA, Akatsu T, Taga EM, Consolaro A. Assessment of the antiexudative and antiproliferative activities of non-steroidal anti-inflammatory drugs in inflammatory models developed in rats by subcutaneous implantation of bacteria cell walls from the dental plaque. Inflammation. 1996;20(6):623-36.

8- Ignarro LJ, Byrns RE, Buga GM, Wood KS. Endothelium-derived relaxing factor from pulmonary artery and veins possesses pharmacology and chemical properties identical to those of nitric oxide radical. Circ Res. 1987;61(6):866-79.

9- Keremi B, Lohinai Z, Komora P, Duhaj S, Borsi K, Jobbagy-Ovari $G$, et al. Antiinflammatory effect of BPC 157 on experimental periodontitis in rats. J Physiol Pharmacol. 2009;60(7):115-22.

10- Kerezoudis NP, Olgart L, Edwall L. Differential effects of nitric oxide synthesis inhibition on basal blood flow and antidromic vasodilation in rat oral tissues. Eur J Pharmacol. 1993;241(23):209-19. 
11- Koshland DE Jr. The molecule of the year. Science. 1992;258(5090):1861.

12- Malheiros CF, Marques MM, Gavini G. In vitro of the cytotoxic effects of acid solutions used as canal irrigants. J Endod. 2005;31(10):746-8.

13- Murad F. Discovery of some of the biological effects of nitric oxide and its role in cell signaling. Biosci Rep. 2004;24(4-5):45274.

14- Nagem-Filho H, Pereira JC. Evaluation of the irritative potential of some intracanal medicaments in the exudative phase of inflammatory process. Rev Bras Odont. 1976;53(5):35-8.

15- Palmer RMJ, Ferrige AG, Moncada S. Nitric oxide release accounts for the biological activity of endothelium-derived relaxing factor. Nature. 1987;327(6122):524-6.

16- Pappen FG, Souza EM, Giardino L, Carlos IZ, Leonardo MR, Toledo Leonardo R. Endodontic chelators induce nitric oxide expression by murine-cultured macrophages. J Endod. 2009;35(6):824-8.

17- Sen BH, Ertürk O, Pişkin B. The effect of different concentrations of EDTA on instrumented root canal walls. Oral Surg Oral Med Oral Pathol Oral Radiol Endod. 2009;108(4):622-7.

18- Shimauchi H, Takayama S, Narikawa-Kiji M, Shimabukuro $\mathrm{Y}$, Okada $\mathrm{H}$. Production of interleukin-8 and nitric oxid in human periapical lesion. J Endod. 2001;27(12):749-52.

19- Silva FB, Almeida JM, Sousa SM. Natural medicaments in endodontics - a comparative study of the anti-inflammatory action. Braz Oral Res. 2004;18(2):174-9.

20- Silva PT, Pappen FG, Souza EM, Dias JE, Bonetti-Filho I, Carlos IZ, et al. Cytotoxicity evaluation of four endodontic sealers. Braz Dent J. 2008;19(3):228-31.
21- Sousa SMG, Bramante CM, Taga EM. Biocompatibility of EDTA EGTA and citric acid. Braz Dent J. 2005;16(1): 3-8.

22- Spanó JC, Silva RG, Guedes DF, Sousa-Neto MD, Estrela C, Pécora JD. Atomic absorption spectrometry and scanning electron microscopy evaluation of concentration of calcium ions and smear layer removal with root canal chelators. J Endod. 2009;35(5):727-30.

23- Sperandio CB, Silveira LF, Araújo LA, Martos J, Malshe A. Response of the periapical tissue of dogs' teeth to the action of citric acid and EDTA. J Appl Oral Sci. 2008;16(1):59-63.

24- Takeichi O, Hayashi M, Tsurumachi T, Tomita T, Ogihara $H$, Ogiso $B$, et al. Inducible nitric oxide synthase activity by interferongamma-producing cells in human radicular cysts. Int Endod J. 1999;32(2):124-30.

25- Takeichi O, Saito I, Okamoto Y, Tsurumachi T, Saito T. Cytokine regulation on the synthesis of nitric oxide in vivo by chronically infected human polymorphonuclear leucocytes. Immunology. 1998;93(2):275-80.

26- Takeichi O, Saito I, Tsurumachi T, Moro I, Saito T. Expression of inflammatory cytokine genes in vivo by human alveolar bone-derived polymorphonuclear leukocytes isolated from chronically inflamed sites of bone reabsorption. Calcif. Tissue Int. 1996;58(4):244-8.

27- Udaka K, Takeuchi Y, Movat HZ. Simple method for quantitation of enhanced vascular permeability. Proc Soc Exp Biol Med. $1970 ; 133(4): 1384-7$

28- Vasconcelos BC, Luna-Cruz SM, De-Deus G, Moraes IG, Maniglia-Ferreira C, Gurgel-Filho ED. Cleaning ability of chlorhexidine gel and sodium hypochlorite associated or not with EDTA as root canal irrigants: a scanning electron microscopy study. J Appl Oral Sci. 2007;15(5):387-91. 